\title{
FROM EMPLOYEE TO HOMO FABER? CONSIDERATIONS ABOUT UNION RENEWAL AND INFORMAL WORKERS IN BRAZIL AND INDIA
}

\author{
Lorenzo Frangi ${ }^{1}$ \\ Professor of Employment Relations, \\ Department of Organization and \\ Human Resources, \\ School of Management, \\ Université du Québec à Montréal \\ (UQÀM) \\ Montréal, Québec, Canada \\ frangi.lorenzo@uqam.ca
}

\author{
Supriya Routh ${ }^{2}$ \\ France-ILO Chair, \\ Nantes Institute for Advanced Study \\ (IEA) \\ Nantes, France \\ supriya.routh@iea-nantes.fr
}

\begin{abstract}
For the purpose of trade union renewal, it is suggested that trade unions need to convert themselves from being institutions centred on employeremployee relations to open source ones engaged with broader social justice issues. In this article, we offer two elements to the debate on trade union revival: first, we focus on two rapidly emerging economies with a corporatist and statecentered union structure (i.e., Brazil and India); second, in the context of these two countries, we challenge the idea that informal workers are a burden for trade union organizations. We consider the possible contributions that informal workers could make towards the renewal of trade unions in these two countries. We argue that trade unions could take advantage of these contributions if they overcome the employee horizon, which originated in Western countries and excludes millions of workers from its purview in Brazil and India. We propose the concept of "homo faber" as a new horizon for trade union organization, which is inclusive of both formal as well as informal workers.
\end{abstract}

\section{INTRODUCTION}

7 The debate about the "crisis of unionism" (e.g., Hyman 2002; Turner et al. 2001) has been countered by many studies (e.g., Fairbrother and

1 Yates 2003; Levésque and Murray 2006), which focused on different possibilities to foster union renewal, as a "process of change, underway or desired to put new life and vigour in the labour movement to rebuild its 
organizational and institutional strength" (Kumar and Schenk, 2006: 30). Many scholars suggest that unions have to enlarge their horizon to renovate and revitalize themselves from institutions concerned only with employer-employee relations to open source institutions engaged with broader social justice issues (Heery et al. 2012; Fitzgerald and Hardy 2010). This debate is not only limited to Western countries, but has also drawn academic and union practitioners' attention in the global South (Benson and Zhu 2008; Chen et al. 2007; Druck, 2006).

Within the framework of this debate, we focus specifically on the possibility of union renewal in the global South countries through the inclusion of informal workers into the trade union movement (Gallin 2001; Bonner and Spooner 2011). If an overall suspicion has prevailed amongst trade unions over the effectiveness of including informal workers into their fold, our specific aim is to highlight some positive contributions that informal workers could bring to trade unions' revitalization in the global South countries.

Our analysis is based on two national cases, namely Brazil and India. These countries are emerging economies in the global scenario and becoming part of the most prominent and dynamic world economies (e.g., Jain 2006; ECLAC 2011; Dossani and Kennney 2009). Irrespective of the tremendous economic changes, Brazilian and Indian trade unions are still peripheral in character and the informal economy represents a wide share of their economic activities (IPEA data 2009; NCEUS 2008).

In the first section of this article we introduce the major challenges for unionism, with a focus on developing countries. In the second section we underline a specific definition of informal economy and consider three central limitations, highlighted in scholarly literature, for the inclusion of informal workers into trade union organizations. We subsequently analyze the institutional peculiarities of unionism in Brazil and India. In section four, after tracing a general panorama of the relation between trade unions and informal workers in the two countries (i.e., inclusive, partial inclusive, or exclusive), we focus on some important experiences of membership-based organizations of informal workers in waste-picking, since this is one of the most relevant activities in the informal economy (Medina 2007). The organizational experiences of informal workers allow us to propose three principal considerations in the subsequent section. First, we contradict the perceived adverse impact of informal workers on trade unionism; secondly, we identify possible resources for trade unions' revitalization if the informal workers are included; and thirdly, we indicate certain aspects that traditional industry-based trade unions can mobilize in order to attract informal workers. Our analysis challenges the largely taken for granted "employer-employee" horizon for trade union organization. Accordingly, we propose the homo faber concept as a possibly more inclusive new horizon for the overall workforce (including informal workers). 


\section{UNION LIMITATIONS IN RECENT DECADES BEYOND DEVELOPED COUNTRIES}

From the early stages of industrialization the principal aim of unions has been the improvement of employment terms and conditions by exercising institutional pressure towards employers and governments. (Bennet and Kaufman 2007). With the spread of industrialization from the European core countries to the global South (Wallerstein 2004), not only were industrial technologies and productive techniques exported, but as a byproduct, unionism was also on rise in these countries. However, in the global South, unionism assumed distinctive characteristics, essentially because it was molded on economic, political, and cultural environments markedly different from the core industrial countries (Freeman 2009). Especially since the traditional focus of unionism in the industrial heartland countries had been dependent on the employer-employee relation, unions covered only a minority of labour dynamics in the global South countries where a significant number of workers are not party to an employer-employee relation. In these countries the formal economic activities-where employer-employee relation is evident-is coupled with a persistent huge share of informal economic activities, where the employment relationship is blurred or even absent (Chen et al. 2007).

From the 1980s onwards, the world economy underwent profound structural changes, calling into question labour institutions and existing forms of employee representation. Even if the situation has not been identical in all countries, trade unions have generally faced difficulties in adjusting and reacting to these global changes. International studies focusing on this issue of union movement have largely tended towards the conclusion of a widespread "crisis of unionism" (e.g., Hyman 2002; Turner et al. 2001).

In the core industrial countries, the debate about the crisis of unionism is primarily focused around the substantial decrease in union density in the last three decades and its consequences (e.g., Ebbinghaus and Visser 2000; Pedersini 2010). With regard to global South countries, the limitations of union effectiveness in the last decades are substantially debated; trade union ineffectiveness has been attributed to difficulties in reaching, organizing, and representing the huge number of workers that are active outside formal economic activities (e.g., Gallin 2001; Bonner and Spooner 2011). This union ineffectiveness is important because in spite of some evidence of economic developments, informal economic activities have not disappeared over time as was predicted by some scholars, but rather, have been confirmed as expanding and becoming central to the global South economies (e.g., Chen 2005; Dibben and Williams 2012). In many cases often over 75 percent of the labour force is engaged in informal businesses and employment (Jütting and De Laiglesia 2009). 
Brazil and India are two remarkable examples. These two countries are now considered amongst the most prominent national economies on the global level, overcoming their peripheral role in the global economic system (e.g., Jain 2006; ECLAC 2011; Dossani and Kennney 2009). However, two aspects are still central in these two countries, along with the economic development phenomenon. First, dramatic social problems typical of global South countries (e.g., the presence of megalopolises which continue to attract unregulated immigration; deep social differences) are aggravated by an enormous number of informal workers in these two countries. According to IPEA data, nearly half of all Brazilian, and more than 93 percent of Indian workers (NCEUS 2008) are in some way engaged in informal economic activities. Second, Brazilian and Indian trade unions are still marginal in character. In fact, as we discuss in section three, they are only marginally effective in defining national labour dynamics and are especially unable to substantially influence the working conditions of millions of informal workers.

\section{INFORMAL ECONOMY AND TRADE UNIONS' SUSPICIOUSNESS}

The informal economy is generally conceptualized and debated in reference to the formal economy (e.g., Sassen 1994; de Soto 1989). Two analytical perspectives predominate in explaining relations between the two: the dualist and the structuralist approaches. The first approach argues that informal unregulated economic activities exist alongside formal organized and regulated ones, and that the two are not related (Sindzingre 2004; Guha-Khasnobis et al. 2006). The second, on the contrary, underlines the inherent linkage between the formal and informal economy. In this view, the informal economy is considered an intrinsic aspect of global capitalism and a direct byproduct of the deregulation and restructuring processes of the world economy (Castells and Portes 1989; Davis 2006). In fact, many informal activities usually undertake production functions at the lowest level of the production chain of formally registered firms, owned sometimes by large-scale domestic capital and multinational corporations. Hence, according to the structuralist understanding, the boundaries between formal and informal economies are porous and blurred, which is also signified by workers shift from one to the other in response to economic changes (Bosch, Goni and Maloney 2007; Jackson 2011).

The International Labour Organization (ILO) provides a definition of the informal economy that goes beyond the abovementioned perspectives. In fact, according to the ILO, the fundamental characteristics of the "informal economy" are that the concept links informal workers with their work, irrespective of its link to formal undertakings, or the presence of a workplace or an employer (Hussmanns 2004: 1). The location of such informal activities can be in informal or in formal enterprises, or outside either of these. 
Scholars have noted that informal work in the global South is largely relied upon for survival purposes and in the large majority of cases, does not yield to overcome the poverty of workers (Mehrotra and Biggeri 2007). In fact, large proportions of informal economic activities are low paid, highly insecure, and have poor working conditions (NCEUS 2007; Breman 2009; Jackson 2011). Irrespective of the relevance of informal workers in the labour market and the widespread miserable conditions of informal workers, trade unions are generally suspicious and mistrustful about the possibility of involving informal workers in their organizations for several reasons (Bonner and Spooner 2011). Among these reasons, two have been considered prominent with the third being central.

First, in a strategic cost-benefit evaluation, integrating informal workers is considered a counterproductive investment by the trade unions. In fact, in the context of widespread union difficulties, primarily reflected in financial shortages, the integration of informal workers demands significant time and financial resources while offering uncertain future returns. Reaching out to informal workers, who are generally scattered and engaged in a diverse range of activities exerts significant strain on limited resources. Second, unions perceive a mismatch between their organizational goals and the aspirations of informal workers. Many informal workers are primarily concerned with mere survival; a characteristic that is perceived as hampering, or worse, undermining interworker solidarity, one of the fundamental aspects for collective action by unions (Gallin, 2001).

However, the third central hesitation of trade unions in organizing informal workers is that many of them are engaged in self-employment or own account work and accordingly, fall outside the traditional employer-employee horizon of trade union organization; a horizon originated in the core industrial countries, but that excludes millions of people from union protection in the global South (Bonner and Spooner, 2011). But, are informal workers just a burden for trade unions? Are there resources that informal workers can bring forth for union renewal in Brazil and India? We address these issues in the following sections.

\section{BRAZILIAN AND INDIAN TRADE UNIONS: MARGINAL IN CHARACTER}

In order to answer the above questions, the first step is to highlight the characteristics of Brazilian and Indian trade unionism.

\section{BRAZIL: THE CORPORATIVE STRUCTURE AND THE DOWNTURN}

The current features of Brazilian trade unionism are primarily the outcome of a corporative and demiurgic state-centred, top-down interventionist policy during the 1940s (Kaufman, 2004). During that period, the state, through central 
planning promoted the interests of the emerging industries and limited the possibility of a bottom-up workers' organization (French, 2001). These policies were mainly pursued through the promulgation of a fundamental law: Consolidação das Leis do Trabalho-CLT (1943, Vargas government). ${ }^{3}$ The CLT defined the structure and strictly limited the action of collective actors in industrial relations. Moreover, the CLT detailed the manifold dynamics of the labour market with a paternalistic approach towards workers. Brazil is defined as a legislado (legislated) model of industrial relations because labour dynamics are principally determined by law and the outcome of collective bargaining processes is marginal (Noronha, 2000). In any case, the huge volume of labour market laws do not include any specification about informal workers-an omission that has excluded a significant share of Brazilian workers from the paternalistic coverage of the CLT rights.

In Brazil, the CLT requires the Labour Ministry to recognize a single union (called sindicato de base) in each territory (i.e., one municipality or a cluster of a few) for all the workers in a specific sector and with a specific profession. This legal principle results in a highly fragmented union representation, even inside the same firm, which seldom come together in supra-territorial or national union organizations (Cardoso and Gindin 2009) ${ }^{4}$. Furthermore, each sindicato de base has the right to receive revenues from a public tax (imposto sindical) applied to all workers of a specific territory and specific profession, irrespective of workers' affiliation to a union. Therefore, there is a weak relationship between the economic resources available to unions and the number of their affiliates.

Unions, largely ineffective in industrial bargaining, have exploited the stateembeddedness of the industrial relations scenario and have invested much energy into political bargaining (i.e., lobbying the state organisation) through political parties as well as establishing direct relationships with the state apparatus in order to influence labour regulation (Schneider 2009).

If unions had a central role in triggering the overthrow of the military regime (1985) (the period called novo sindicalismo [new unionism]), they have faced hard times afterwards (Sluyter-Beltrão 2010). Union hardship was more visible during the 1990s as a result of the great economic transformation of Latin America: the neoliberal turn (Weyland 2007). Three changes in the labour market particularly weakened the trade unions in Brazil (Ramalho 2010): employment shrinkage in the traditionally unionised sectors; large outsourcing, which contributed to a substantial erosion of the traditional form of employment covered by the CLT (carteira assinada) in favour of the emergence of the atypical forms (i.e., selfemployed, own-account, cooperatives, among others); and, the substantial increase of the informal economy between the early 1990s and 2002 (which then slightly decreased).

Since the 1990s, the trade union crisis in Brazil is both quantitative as well as qualitative. First, there was a substantial decrease in the number of affiliated 
employees. According to IPEA (Instituto de Pesquisa Econômica Aplicada) data, union density was estimated around 11 percent at the end of the 1970s, during the military regime; then during the novo sindicalismo experience it rose to 32 percent; in the neoliberal era it decreased to 15 percent, and recovered afterwards to reach 20 percent in 2009. Second, union affiliation has also gone through a qualitative change. The ideological appeal of the unions that attracted many during the military regime, substantially faded with the return of democracy and therefore, militancy amongst affiliates reduced dramatically (Murillo and Shrank 2010).

As a consequence of the quantitative and qualitative downturn, trade unions have essentially pursued a defensive strategy since the neoliberal turn of the Brazilian economy (Pochmann 2007). On one hand, unions tried to focus on a narrower array of employees, especially in sectors where unions were less disturbed, in particular in the public sector. The core membership target for unions shifted from industrial blue-collar workers to the public sector whitecollar workers. On the other hand, unions tried to revitalize their link with political parties and politicians to survive as an influential institution on the political and media front (Murillo and Shrank 2010; Schneider 2009).

\section{INDIA: EXCLUSION OF MILLIONS OF WORKERS AND STATE-CENTRED UNIONISM}

During the pre-independence era, while the British intended to establish and control trade unions in India for strategic administrative purposes, they soon realized that industrial and labour conditions in India were not similar to the ones prevailing in the United Kingdom. The significant majority of Indian workers laboured outside the industry setup. The large diverse ranges of informal economic activities that Indian workers were engaged in were not conducive to trade union organizations. Accordingly, British colonial officers concluded that Indian workers could not be organized in trade unions (Wolcott 2008). The trade union movement did not establish roots in India until the 1920s (discussed presently).

After the Indian independence in 1947, the government pursued a planned industrialization policy. Similar to Brazil, the Indian government's primary strategy to control industrial relations was through legislative mechanism. Two of the most important industrial relations statutes in India are the Industrial Disputes Act 1947 and the Factories Act 1948. The first seeks to establish "industrial peace" and the second imposes liability on the employer for the safety, health, and welfare of workers employed in factories, thus, detailing many aspects of the labour-management dynamics. However, none of these two legislative pillars include any labour rights extendible to informal workers. Accordingly, informal workers, who constitute the significant majority of the 
working population in India, remain excluded from major statutory safeguards (NCEUS 2007).

Establishment and registration of trade unions in India is dealt with by the Trade Unions Act 1926. Any seven individuals can constitute a trade union as a temporary or a permanent entity. ${ }^{5}$ However, there is no Parliamentary law or provision on mandatory recognition of trade unions for bargaining purposes. Therefore, employers are free to bargain with any trade union of their choosing. As a consequence of these legislative principles two structural aspects of Indian trade unionism emerged: one, a high organisational fragmentation in the trade union movement (because the minimum membership requirement is only seven); and second, the most influential trade unions developed a close linkage with political parties in order to achieve a wider social relevance (because of the absence of laws for union recognition) (Gillan and Biyanwila 2009).

Established in 1920, the communist-ideology-dominated All India Trade Union Congress (AITUC) was the first national federation of trade unions in India, which then split several times due to political divergences in the postindependence era (Ali 2011; Bhowmik 2009). In 1947, the ruling party, the Congress-I, introduced its own trade union, the Indian National Trade Union Congress (INTUC), in order to receive working class support for government policies. This initiative established a double link between the government and unions-one direct and the other mediated by the party. Thus, the most important trade unions became more dependent on the government (Bhowmik 2009: 52). However, between the 1960s and 1979, due to industrial stagnation and unemployment, many workers were disillusioned with the INTUC, which resulted in a proliferation of radical and independent trade unions, and propelled inter-union rivalries. Independent unions also increased between 1980s and 1991 (Bhattacherjee 2001).

Because of the major trade unions' close link with the government and political parties, and the centrality of labour laws for industrial relations, the industrial relations scenario in India has mainly been a state-centric phenomenon. This is especially evident in bargaining dynamics, which are largely concentrated in the public sector (the large majority of formal employment). Moreover, the government has a monopoly over the industrial dispute resolution mechanism, which hardly allows any scope for collective bargaining and agreement (Sen Gupta and Sett 2000).

In 1991, a significant change occurred in the Indian labour market, which resulted from the political turn towards opening of the Indian market to the global economy. Post-1991, labour flexibility and informality substantially increased in India (Ghosh 2008). Labour flexibility further increased the already wide array of informal workers up to an enormous level (more than 90 percent as above mentioned), while the majority of the formal workers remained in the public sector. Additionally, the distinction between formal and informal became 
increasingly blurred, due to the frequent worker transition from the one to the other (NCEUS 2008: 44).

In the post-1991 period, trade unions were perceived as an inhibiting factor towards the liberalization of the economy. Both central and state, governments introduced reforms that would substantially reduce the already deplorable bargaining power of trade unions. Unions concentrated more and more on fewer formal workers-essentially the public sector white-collar workers (Kuruvilla and Erickson 2002; Bhangoo 2006; Rao 2007) - and suffered substantial losses in terms of union density. Due to this, some unions internally debated the possibility to also organize informal workers (Sundar 2008: 160-162).

\section{UNIONS, INFORMAL WORKERS, AND NEW FORMS OF ORGANIZATIONS IN THE TWO COUNTRIES}

The persistence of the fundamental historical characteristics of Brazilian and Indian trade unionism, respectively corporative-ism and state-centeredness, seems at first instance, to be a strong restrictive cage to foresee any possibility of union renewal. The negative conjuncture of a neoliberal economic direction seems to further restrict this possibility. In the backdrop of this gloomy picture, some positive resources could be highlighted if unions are open to look outside the narrow employer-employee horizon.

This section thus focuses on two aspects. The first is the characteristics of the relation between trade unions and informal workers. According to Cervino (2000), trade unions' strategies towards informal workers can be classified as: exclusive, when trade unions completely exclude informal workers from their organizations; partially inclusive, when unions make some efforts to organize informal workers; or totally inclusive, when informal workers are completely included in the horizon of the union organization. The second aspect engages some relevant examples of membership-based organizations of informal workers in the two countries, with a focus on waste-pickers' organizations. This discussion will subsequently enable us to highlight some resources that informal workers could bring for union renewal.

Trade unions in Brazil adopt a partially inclusive strategy towards informal workers. Since the 1990s, after the quantitative and qualitative crises of trade unions, in addition to defensive strategies they tried some expansive ones. Trade unions have essentially attempted to reach a broader target than solely formal employees through the promotion of initiatives aimed directly or indirectly at reaching and organizing informal workers. However, these initiatives have been highly ineffective, selective, and characterized by a marginal organizational and financial investment (Ramalho 2010).

According to the report of the Solidarity Center of 2012, there are few instances in which trade unions attempted to directly organize informal workers. 
These experiences are generally locally based. One example is the SINTEIN (Sindicato dos Trabalhadores na Economia Informal de São Paulo; Union of workers in informal economy of São Paulo) that was organized as an umbrella union for informal workers by the CUT (Central Unica dos Trabalhadores) of São Paulo. Other selective initiatives have been undertaken by the CUT in Rio de Janeiro and in Sergipe to organize a sector largely marked by informality (i.e., domestic workers by the Sindicato das trabalhadoras domésticas do Rio de Janeiro and Sindicato das trabalhadoras domésticas do Sergipe).

Unions have also attempted to reach informal workers indirectly, mainly through collaboration with state actors, national and international NGOs, and community-based organizations through projects promoting the welfare of lower income citizens, most of whom are active in the informal economy (Ramalho, 2010). Frequently, in these mostly state-funded projects, unions are often indicated as the leading organizations because of their well-established organizational structure and their long lasting relations with the state apparatus.

In particular, CUT established a new national department in 1999 (Agência de Desenvolvimento Solidário/CUT) focused on the sustenance of the economic solidarity initiatives, most of which are targeted towards informal workers. In this case, trade unions have primarily concentrated their actions in providing some technical support-and not co-opting informal workers into union membership-in order to sustain already exiting solidarity-based economic initiatives, such as microenterprises and cooperatives, some of them in wastepicking activities. Additionally, we have to note, as argued by Lima (2007) and Souza (2008), many of the unions promoting solidarity-based economic initiatives contribute to the erosion of the core employee profile (carteira assinada), which has already been largely destabilized by neoliberal policies.

Even if unions are not markedly active in organizing informal workers, informal workers have demonstrated that they are not amorphous. There are several examples of informal workers' membership-based organizations in the country and in the informal waste-picking activity in particular (Velloso 2005; Dias 2010; Coletto 2010; Coelho and Godoy 2011). Even though these organizations principally promote the economic interests of the members, many of them are engaged with broader social right issues of the members (Coletto 2010).

Some membership-based organizations developed important networks of collaboration amongst themselves in order to promote the economic as well as social rights of their members. De Aquino et al. (2009) described some cases of economic collaboration amongst the waste-pickers' organizations in the South of Brazil. Dias (2010) underlines that self-managed waste-pickers' organizations demonstrate the ability to come together through the federation, especially to facilitate social rights of the catadores. For example, the CATAUNIDOS unites eight waste-pickers' self-managed organisations in the region of Belo Horizonte. 
This is not an isolated instance. Several similar experiences of the federation of waste-pickers' organisations are widespread in Brazil (e.g., CENTCOOP in Brasilia; CATASAMPA in São Paulo; CATABAHIA in Salvador; FARRGS in Rio Grande do Sul state).

Moreover, many of the waste picking federations come together in the Movimento national dos Catadores de materiais reciclaveis (National Association of Garbage Collectors). This national association wants to "contribute to the construction of a fair and sustainable society starting from the social and productive organization of the catadores and their families" (Mission declaration of the movement). The Movimento national dos Catadores de materiais reciclaveis was able to organize two congresses in 2001 and 2005 with considerable participation of many waste-pickers' associations and political organizations (Coletto 2010). In any case, the national association of catadores, as well as the abovementioned federations, organize outside the typical employer-employee relation, which is the central conceptual element established by the CLT in the recognition of a union.

Similar to the Brazilian trade unions, Indian trade unions also adopt a partially inclusive strategy vis-à-vis informal workers. Even though the well known large trade union federations have been able to integrate certain categories of informal workers (such as construction and bidi workers) into their fold, those federations have not been able to bring the majority of informal workers into their membership.

As a result of exclusion from the scope of traditional trade unions, newer modes of organization employing innovative organizational strategies amongst informal workers are taking shape (Webster 2011). Amongst the several forms of self-organization of informal workers (e.g., trade unions, co-operative societies, and charitable trusts), the Self Employed Women's Association (SEWA) and the Kagad Kach Patra Kashtakari Panchayat (KKPKP) in India are nationally remarkable experiences because they are organized and legally recognized as trade unions.

Registered in 1972, SEWA is a trade union that organizes self-employed women workers engaged in varieties of economic activities including wastepicking (Kapoor 2007). The SEWA was born out of a formal trade union - the Textile Labour Association (TLA), but once created, it had to sever its ties from the TLA (Bhowmik 2007: 124). After this split, its recognition was difficult, as it moved beyond the narrow concept of employer-employee relations and integrated informal self-employed workers into its fold. ${ }^{6}$ SEWA's primary functional focus is on the socio-economic betterment of its members. SEWA unionization facilitates recognition of informal workers and their activities (Hill 2010). The union aims to promote full-employment of its members in order to ensure their security at work, while also seeking to improvements with respect to income, food, and social security (Bhat, 2006). 
In 2009, SEWA had 1,256,944 members across India, among them 631,345 members in the state of Gujarat. SEWA's financing is based on annual membership contribution from members (of five rupees) and donations from a range of government and private donors, Indian and foreign. The trade union's governance is carried out by a mix of professional cadres and informal worker members - high levels of participation by members in all aspects of the union characterise SEWA functioning (Bhat 2006).

Even though delivery of services is the primary goal, SEWA's role is not limited to it. SEWA has a strong external presence (both national and international) in the policy-development sphere. Counting on the members' engagement and participation, SEWA lobbies the government on several issues in favor of informal workers and against myriad forms of discrimination against women informal workers (Dave, Shah and Parikh 2009).

The Kagad Kach Patra Kashtakari Panchayat (KKPKP) is another important example of the non-amorphousness and organisational strength of informal workers in India. ${ }^{7}$ The KKPKP is a union of waste-pickers in Pune, Maharashtra. KKPKP registered itself as a union in 1993 (Antony 2001). Unlike SEWA, KKPKP admits both men and women members (Chikarmane and Narayan, undated). One of the principal purposes of the union is to promote waste-picking as productive, valuable, and meaningful work in order to ensure that waste-pickers are recognized and respected as workers (Shekar 2009). The KKPKP works on the same principles that SEWA adopts in its functioning. While on one hand the KKPKP organizes to provide for socio-economic benefits to its members, on the other, it mobilizes its members for direct political action and lobbying.

Like Brazil, waste-pickers' organizations in India are also developing coalitions in furthering their interests. The KKPKP became part of a coalition of eight waste-pickers' organizations from the states of Bihar, Delhi, Gujarat, Karnataka, Madhya Pradesh, and Maharashtra, who forged an alliance called SWACHH in 2005 (KKPKP, 2009). The KKPKP functions as the secretariat for the alliance. SWACHH is currently constitutive of twenty-four organizations working with waste-pickers' problems. SWACHH prepared a national policy on solid waste management, and proposes to lobby government(s) in order to implement their policy proposal. Issues such as gender discrimination, door-todoor waste collection, organizational assistance, and networking are some of its mandates.

These informal workers' organizations are mostly ignored by formal sector trade unions. Accordingly, scholars note that the major challenge for traditional trade unions in India today is to successfully integrate the "interests and objectives" of informal workers (Haan and Sen 2007: 80). 


\section{INFORMAL WORKERS ARE NOT JUST A BURDEN FOR UNION ORGANIZATIONS}

The important examples cited above allow us to underline some elements that cannot only counterweight the most critical concerns about the integration of informal workers as part of traditional trade unions, but can also highlight some positive contributions that informal workers can bring to revitalize trade unions in these two countries. Finally, we underline some fundamental elements that can attract informal workers towards trade unions.

\section{COUNTEREVIDENCE TO INFORMAL WORKERS' INVOLVEMENT IN TRADE UNIONS AS A BURDEN}

Critics of traditional trade union involvement in organizing informal workers have underlined that cost-benefit analysis is not favorable for such an endeavor (as discussed earlier) - given that they entail extensive financial investments with only low potential returns and an uncertain future. However, if we focus on the Brazilian and the Indian cases, some positive considerations have to be added to this perspective. In fact, two positive aspects can partially counterweight this possible adverse influence of integrating informal workers.

First, in both the countries the number of informal workers runs into the millions. Under such circumstances, even though there are possible difficulties in reaching out to informal workers, possible membership contributions (even small amounts) from informal workers could positively impact shrinking trade union revenues, the result of recent economic openness in these two countries.

From this point of view, membership-based organizations of waste-pickers (i.e., SEWA and KKPKP) are Indian examples which counter the draining of financial resources argument. In fact, informal workers are capable of contributing regular membership fees to union funds and sustaining revenue for regular union activities (Bhat 2006). In Brazil too there is much evidences of selfmaintaining organisations of catadores. As is evident from the trade union initiatives of waste-pickers in both the countries, instead of being passive recipients of benefits, informal workers are responsible and active agents in the maintenance and promotion of collective efforts through their own organization initiatives and personal contributions. This evidence suggests that perception regarding the integration of informal workers into traditional trade unions as a heavy burden on the financial efficiency of the unions is not always sustainable.

Cost-benefit considerations about organizing informal workers as part of traditional trade unions must consider one further point. In both countries, especially since the neoliberal turn in Brazil and the post-1991 period in India, borders between formal and informal economies are becoming more blurred, as many workers transitioned from formal to informal activities. From a spot 
presence limited to employee moments, trade unions should become a constant presence in the lives of workers if they seek to occupy a larger organizational horizon. This continuous organizational link can positively influence the inclination of workers to join affiliations when they are active in the formal labour market, and in turn, have positive effects on trade unions' membership revenues.

For the Brazilian case we have to underline that unions can also count on significant public contributions (imposto sindical). Moreover, according to more recent ECLAC data, in the last ten years formal employment has increased in Brazil and the union affiliation rate is also having a slightly positive trend. These two elements can also increase the revenue available to unions and contribute to promote the efforts of organizing a larger worker horizon.

A stronger critique to the possibility of organizing informal workers as part of traditional trade unions is that they are amorphous and individualist, and therefore, not oriented to collaboration and collective dimension. A first general counterpoint is that informal workers have the distinctive characteristic of being accustomed to struggle and resistance, since they struggle for their everyday survival. They undertake a myriad of daily practices of resistance to conquer social spaces and social respect (Scott 1985; 1990; Bayat 2004). Taking lessons from the Brazilian and the Indian cases we can underline some trends that open up space for a counterargument against the individualist and amorphous nature of informal workers. In fact, in both countries informal workers demonstrate the ability to overcome their individualism and to come together in organizations that advocate on their behalf.

More particularly, in SEWA and KKPKP in India, informal waste-pickers collaborate and undertake collective action at several levels, both internal to the trade unions and with external institutions. Internally, both organisations have constituted multiple cooperative societies in order to assist waste-pickers. Collaborative activism of waste-pickers also extends outside the trade union framework. Waste-pickers of these trade unions have successfully bargained with local administration and several levels of the government structure. Wastepicker members of both SEWA and KKPKP have successfully engaged in collective action to negotiate with local governments to further their contract for door-to-door domestic waste collection. At the political level of collective action, both SEWA and KKPKP have undertaken agitation against the state governments of Gujarat and Maharashtra. Moreover, as we have indicated earlier, waste-pickers' organizations have formed alliances amongst themselves for the purpose of bargaining with the national government. ${ }^{8}$

In Brazil and India the waste-pickers' organisations are an important representative case of collaboration. Not only do informal workers come together into an organisation, but the different organisations also come together in larger federations, sometimes in a national federation. Moreover, many of the waste- 
picker organizations entered into relations with public actors in order to achieve contracts for waste collection (Velloso 2005; Pereira and Teixeira 2011). They thereby demonstrate their capacity to collectively interact with public actors and to be accountable for their actions.

\section{SPECIFIC RESOURCES THAT INFORMAL WORKERS CAN BRING FOR UNION REVITALISATION}

Not only does analysis of the Brazilian and the Indian cases suggest some counter-evidence to concerns regarding the negative impact of informal workers in unions, it also underlines three specific resources that informal workers in both countries can offer for union renovation. An appreciation of these possible strategic resources could sensitize a union to adopt a more inclusive perspective on membership, rather than favoring a closure with narrower core members.

First, in both countries the opening of the national economy to global challenges since the 1990s has largely eroded the already feeble union strength. Even if there are some little signs of recovery, the current trade union density is far away from the glorious era of novo sindicalismo in Brazil, when unions had a relevant social protagonism. Similarities can be seen with the Indian case where unions became even more fragmented and marginal social actors in the industrial relations scenario.

In Brazil, after the neoliberal turn, trade unions have followed a defensive strategy, mainly targeting white-collar public sector employees for membership. The public sector white-collar employees are a category of workers whose rank and file activity is historically limited. Similarly in India, in the postliberalization era, unions have mostly drawn their strength from public sector workers who constitute a small minority of workers in the country.

A shift from formal employees to a wider worker horizon can provide unions with higher probabilities to maintain the critical mass to persist as a reliable social and political force, in terms of the numbers of workers represented. Moreover, by targeting informal workers in addition to formal employees, unions can benefit from the shift from a concentration of white-collar public sector workers - who generally enjoy high salaries and good working conditions in these countries - to the incorporation of the vitality, resistance habits, and experience of informal workers shaped by the hardship of their working conditions. This qualitative membership change could also contribute towards trade union renovation.

Second, including informal workers into union membership will also pose an open challenge to the structural state-centred features of the Brazilian and Indian industrial relations dynamic. In Brazil, union efforts to organize informal workers in their regular membership-and not as marginal constituents, as observed-can be a way to open a fissure in the corporative iron cage of 
unionism as determined by the CLT. In fact, the CLT and the other laws about trade unions do not take into account any possible representation of informal workers. In India, the three primary legislations regulating industrial relationsthe Industrial Disputes Act, 1947, the Factories Act, 1948, and the Trade Unions Act, 1926-all take industrial employees as their point of reference and accordingly, leave informal workers from the purview of legislative safeguards. SEWA challenged this strong employer-employee framework of labour laws despite being initially refused registration as a trade union because its members were not employed in an establishment. However, the union got registered by challenging the predominant notion of employment in an establishment. In any case, its self-employed members remain organized separately from (formal) employees. A wider organizational horizon by Indian unions can overcome this mutually exclusive organizational dualism (i.e., unions for formal and unions for informal workers) and thereby largely challenge the dense labour law apparatus that excludes millions of workers.

Third, trade unions in Brazil and in India are a highly fragmented organizational lot characterized by many divergences. In Brazil, the numerous sindicatos de base organized along professional and territorial cleavages and in India, the different national party-linked and independent unions undermine the unity of a comprehensive collective representation. Even if the first impression about the inclusion of informal workers suggests that just another dimension is being added to the already fragmented trade union movement in these two countries by the inclusion of the informal workers into their organizations, the trade unions can create new spaces of convergence and develop possible agendas for collaboration. In fact, informal workers are transversally widespread in different sectors, professions, and regions but share important common characteristics, specificities, and necessities. Integrating informal workers can, in turn, provide an important point of agenda-convergence amongst many different unions in Brazil, as well as in India. Some evidence of this convergence has become apparent recently in India (Sundar 2008: 170-172).

\section{ELEMENTS FOR ATTRACTING INFORMAL WORKERS}

Even if trade unions open up to informal workers, the participation and affiliation of the latter is not automatic. One of the pillars in the union renewal debate is that, even in a general negative conjuncture such as the neoliberal turn for Brazil and India, unions must focus on a few specific strategic resources already available to them that can trigger revitalization (i.e., those that could motivate informal workers to join unions in our case). Analysis of the Brazilian and Indian trade union scenarios allows us to underline two common fundamental resources that trade unions can mobilize in order to attract informal workers, namely the organizational and the political. 
In the first case, trade unions have fundamental organizational resources. In fact, they are well settled institutions in both countries for many years. Unions are amongst the oldest civil society associations. They are present in many different regions of these countries and can count on a non-precarious body of office bearers. This is the case of some of the most important political partylinked unions in India. In Brazil, due to the non-precarious organizational structure, government(s) frequently involve unions as a lead actor for social projects, especially those that are primarily targeted towards informal workers.

Second, unions in both countries have fundamental political resources. In Brazil, unions are characterized by a state embeddedness that is often considered to limit their actions. However, unions strategically exploited this political embeddedness to influence labour dynamics through the political arena, especially through parties and political exponents close to unions. Likewise, since the major trade unions in India are affiliated with the major political parties, trade unions enjoy close proximity to the government and the legislature.

This state embeddedness of unionism in India and Brazil has twofold significance. If, on one hand, it is a characteristic that differentiates unionism in these countries from European experiences, on the other, they could represent a resource to foster labour rights and working conditions for informal workers. In fact, unions can exploit their well-developed channels to the political arena to overcome political indifference towards informal workers and to centrally propel changes in their conditions of work. Rather than focusing exclusively on industrial bargaining that always covered a limited share of workers in these two countries, trade unions can count on spaces of political bargaining for the promotion of informal workers conditions, an important selective incentive to involve informal workers in trade unions. Fostering political influence, especially on issues that influence a huge number of workers, as Freeman (2009) argues, means fostering an aspect of union vitality.

These organizational and political resources are two aspects that can strike a synergy. On one side, the organizational resources of Brazilian and Indian unionism are fundamental elements to contact, achieve, and organize informal workers inside unions-a resource at the bottom. At the same time, through political resources unions can bring and foster in the political arena the enhancement of informal workers' conditions-a resource at the top. A synergy between these bottom- and top-level resources should facilitate union renewal that assumes a perspective of a larger organizational horizon.

\section{VI. “HOMO FABER" AS A POSSIBLE LARGER HORIZON?}

If trade unions remain trapped in the employer-employee horizon, not only will they exclude millions of workers who experience poor working conditions devoid of dignity from their protection, but they will also fail to take advantage 
of some important resources that informal workers can contribute to their renovation. The necessity for a wider organizational horizon for unions is not a novelty. The conflation of workers with employees has been largely debated and criticized (e.g., Kaufman and Daphne 2000; 2006). Of late, trade unionism and legal protection for non-employee workers has emerged as an intense and urgent debate (Freeman and Rogers 2006).

Though, for us the worker organizational horizon does not seem the most appropriate to make Brazilian and Indian unions open source institutions engaged with broader social justice issues. The worker horizon still seems to evoke, at least in its background, a capital-labour relation. Thus, the inclusion of the many millions of Brazilian and Indian informal workers who are self-employed or ownaccount workers (many engaged in mere survival activities) in trade unions does not become evident (the third, and most important, limitation for unions in organizing informal workers, as discussed in section one).

We thus propose the homo faber as the new horizon for unions. As Ferrarin (2000: 289-290) argues, through the faber action, human beings control their own destiny and at the same time, derive their dignity and human worth through their creations, and accordingly, their labour. We specifically invoke the idea of homo faber in order to suggest a productive work performed by any worker-man or woman, formal or informal. Accordingly, the homo faber concept allows for relating the work of creating with the worker who creates. The advantage of invoking the homo faber concept is that it helps in conceptualizing labour and workers beyond the formal dichotomies of capital and labour. In fact, it allows for linking workers' conditions primarily to their working activity, and not to their (formal) legal status.

Thus, the homo faber horizon includes employees (i.e., workers legally hired by an employer) and additionally, varieties of informal workers (e.g., selfemployed, on their own, participating in family activities, informally employed by formal or informal firms or cooperatives). However, some limits to the concept must be emphasized. Homo faber horizon does not include people engaged in informal activities that do not produce (faber) goods or services (e.g., begging) or criminal activities (e.g., drug sellers). While exclusion of begging as a non-productive activity from the scope of the homo faber concept is self-evident, some might consider criminal activities such as transaction of drugs productive for the mere fact that something is being produced and sold. While the relation between criminal work and non-criminal work is a complex one, suffice it to say that since society patently criminalizes these transactions, we exclude it from our homo faber perspective.

Thus, we argue that the homo faber perspective can successfully facilitate the possibility for unions to overcome the most constraining aspects in organizing and representing informal workers and to take advantage of their resources to renovate and reinvigorate as an effective institution. Even if informality seems to 
be difficult to overcome shortly, mainly in countries with high rates of economic growth as Brazil and India, the homo faber perspective might help in integrating informal workers into the mainstream trade union movement. The possible positive effects are not only limited to reviving the waning trade union movement and facilitating improvements in informal workers' conditions, but also to limit the negative pressure of the informal "reserve army of labour" on formal workers.

\section{CONCLUSION}

In India and Brazil, countries that have passed through a dramatic economic growth in the more recent years, informal activities represent a substantial share of labour market occupations. Moreover, these countries are characterized by mainly corporative and state-centered unionisms, not particularly effective in defining labour conditions.

Additionally in these two countries, and more generally in the global South, unions are generally suspicious about the possibility of integrating informal workers into their membership. Involving informal workers is considered a financial drain. Moreover, informal workers are considered amorphous. However, the most significant limitation in organizing informal workers is that they fall outside the traditional employer-employee relation. We challenged these three aspects and attempted to offer a different perspective, (i.e., one in which informal workers can bring resources to union revitalization).

First, it is a matter of number and representation. Through the organization of informal workers in India and Brazil, unions can gain a critical mass and get closer to lower level workers and not just remain the representative of a marginal and wealthier share of workers such as the white-collar elite public workers. Second, the inclusion of informal workers can pose a challenge to the statecentered corporative structure of industrial relations in the two countries, thereby opening some fissures in the legal iron cage that does not take into account the millions of informal workers. Third, the organization of informality can become an element that can promote agenda convergence and links among the highly fragmented union structure in Brazil and India.

In order to take advantage of the resources that informal workers can bring to revitalize unions, a significant change in the union organizational horizon is required. We propose the homo faber perspective as the new union horizon, which is inclusive of both formal and informal workers. This radical change is not easy, but the stakes are high for the integration of informal workers. It can become a turnaround in the prevention of human misery, still high in both the countries, and in the promotion of a wider distribution of the positive economic growth that Brazil and India are undergoing, which has not yet benefitted the majority of informal workers. 
61 Just Labour: A Canadian Journal of Work and Society - Volume 21 - Spring 2014

\section{NOTES}

1 Dr. Frangi also collaborates with the Interuniversity Research Centre on Globalization and Work - Centre de recherche interuniversitaire sur la mondialisation et le travail (CRIMT).

2 Work on this article was done as a Rechtskulturen Fellow at the Faculty of Law, Humboldt University, Germany.

3 "Consolidação das Leis do Trabalo" (CLT) can be translated as the consolidation (in the sense of systematization) of labour laws. CLT is a collection that comprises several labour laws from 1930, clearly influenced by the fascist labour code previously emitted by Mussolini in Italy (Cook 2007).

4 For example, in the Brazilian division of a multinational corporation Frangi (2012) counted more than 120 sindicatos di base. Among national unions organizations (centráis sindicais), the most important ones are: CUT (Central Única dos Trabalhadores) that is placed on progressive positions; and FS (Força Sindical), which is comparatively more conservative.

5 The Act also charts out the rights and obligations of members of registered trade unions. However, if a trade union is not registered as per the law, members of the trade union do not enjoy statutory rights provided under the Trade Unions Act.

6 Based on the Trade Unions Act, 1926, definition the Labour Department refused to register SEWA as a trade union, reasoning that since there were no recognised employers, workers of the union would have no one to bargain or struggle against. SEWA argued that a trade union does not need to be posed against employer(s) since the primary purpose of a trade union is the promotion of unity amongst workers. See SEWA(c); Bhat 2006: 9-10, 17-18.

7 Kagad Kach Patra Kashtakari Panchayat (KKPKP), available at http://www.wastepickerscollective.org/ (site visited 7 June 2012).

8 At the national level an example of lobbying success is the constitution of the NCEUS under pressure from the trade unions in the country. Trade Unions such as SEWA had been instrumental in pursuing the Commission and the resultant legislation (Bhat 2006; Hill 2010: 76-77). National Commission for Enterprises in the Unorganised Sector (NCEUS) constituted by the Government of India in the year 2004 (Reserve Bank of India 2008).

\section{REFERENCES}

Ali, S. 2011. "Indians on Strike-Caste and Class in the Indian Trade Union Movement". New Labor Forum. 20(2): 33-39.

Antony, P. 2001. Towards Empowerment: Experiences of Organizing Women Workers. New Delhi: ILO.

Bayat, A. (2004): "Globalization and the Politics of the Informals in the Global South". Pp. 79-102 in Urban Informality: Transnational Perspectives from the Middle East, Latin America, and South Asia, edited by A. Roy and N. Alsayyad. Lanham, MD: Lexington Books,. 
Bennet, J. T. and B. E. Kaufman. 2007. "What Do Unions Do? A Twenty-Year Perspective." Pp. 1-11 in What Do Unions Do? A Twenty-Year Perspective, edited by J. T. Bennet and B. E. Kaufman. New Brunswick, New Jersey: Transaction Publishers.

Benson, J. and Y. Zhu. 2008. Trade Unions in Asia - An Economic and Sociological Analysis. London: Routledge.

Bhangoo, K. S. 2006. "Trade Unions in Globalised Economy of India". Indian Journal of Industrial Relations 41(4): 397-405.

Bhat, E. R. 2006. We Are Poor but So Many: The Story of Self-Employed Women in India. New York: Oxford University Press.

Bhattacherjee, D. 2001. "The Evolution of Indian Industrial Relations: A Comparative Perspective". Industrial Relations Journal 32 (3): 244-263.

Bhowmik, S. K. 2007. "Co-operatives and the emancipation of the marginalized." Pp. 122-137 in Membership-Based Organizations of the Poor, edited by M. Chen, R. Jhabvala, R. Kanbur and C. Richards. New York: Routledge.

Bhowmik, S. K. 2009. "Understanding Labour Dynamics in India". South African Review of Sociology 40(1): 47-61.

Bonner, C. and D. Spooner. 2011. "Organizing Labour in the Informal Economy: Institutional Forms \& Relationships." Labour, Capital and Society 44(1): 127152.

Bosch, M., E. Goni and W. F. Maloney. 2007. “The Determinants of Rising Informality in Brazil: Evidence from Gross Worker Flows". IZA Discussion Papers 2970, Institute for the Study of Labor (IZA).

Breman, J. 2009. "The Myth of the Global Safety Net". New Left Review 59: 29-38.

Cardoso, A. and J. Gindin. 2009. "Industrial Relations and Collective Bargaining: Argentina, Brazil and Mexico Compared". ILO working paper no.5.

Castells, M. and A. Portes. 1989. "World Underneath: The Origins, Dynamics and Effects of the Informal Economy." Pp. 11-37 in The Informal Economy: Studies in Advanced and Less Developed Countries, edited by A. Portes, M. Castells and L. A. Benton. Baltimore: John Hopkins University Press.

Cervino, E. 2000. "Trade Union Strategies towards Atypical Workers". European Political-economy Infrastructure Consortium (EPIC), Ionian Conference $2000-$ Challenges of the New Millenium. Corfu, Greece.

Chen, M. A. 2005. "Rethinking the informal economy: linkages with the formal economy and the formal regulatory environment." Pp 72-92 in Linking the Formal and Informal Economy, edited by B. Guha-Khasnobis, R. Kanbur, and E. Ostrom. New York: Oxford University Press.

Chen, M. A., R. Jhabvala, R. Kanbur, and Carol Richards (eds). 2007. Membership Based Organizations of the Poor. London: Routledge.

Chen, M., R. Jhabvala, R. Kanbur and C. Richards. 2007. "Membership-Based Organizations of the Poor." Pp. XX in Membership-Based Organizations of the 
Poor, edited by M. Chen, R. Jhabvala, R. Kanbur and C. Richards. New York: Routledge.

Chikarmane, P. and L. Narayan. Undated. “Organising the Unorganised: A Case Study of the Kagad Kach Patra Kashtakari Panchayat (Trade Union of Wastepickers)." Retrieved June 72012

(http://wiego.org/sites/wiego.org/files/resources/files/Chikarmane_Narayan_cas e-kkpkp.pdf).

Coelho, D. B. and A. S. Godoy. 2011. “De catadores de rua a recicladores cooperados: um estudo de caso sobre empreendimentos solidários." Revista de Administração Pública 45(3): 721-49.

Coletto, D. 2010. The Informal Economy and Employment in Brazil: Latin America, Modernization, and Social Changes. New York: Palgrave-Macmillan.

Cook, M. L. 2007. The Politics of Labour Reforms in Latin America. Between Flexibility and Rights. University Park: The Pennsylvania State University Press.

Dave, J., M. Shah and Y. Parikh. 2009. “The Self-Employed Women's Association (SEWA) Organising Through Union and Co-operative in India." Pp. 27-32 in Refusing to be Cast Aside: Waste-pickers Organising Around the World, edited by M. Samson. Cambridge, MA: WEIGO.

Davis, M. 2006. Planet of Slums. London: Verso.

De Aquino, I. F., A. B. de Castilho Jr. and T. S. De Lorenzi Pires. 2009. “A organização em rede dos catadores de materiais reciclaveis na cadeia produtiva de pós-consumo de região da grande Florianópolis: uma alternativa de agregação de valor." Gestão e Produção 16(1): 15-24.

De Soto, H. 1989. The Other Path: the Invisible Revolution in the Third World. New York: Harper \& Row.

Dias, S. M. 2010. “Gestão de resíduos sólidos, catadores, participação e cidadania - novas articulações?" Relatório de Pesquisa em Políticas Urbanas- WIEGO.

Dibben, P. \& C. C. Williams. 2012. "Varieties of Capitalism and Employment Relations: Informally Dominated Market Economies." Industrial Relations 51 (1): 563-582.

Dossani, R. and M. Kennney. 2009. "Service Provision for the Global Economy: The Evolving Indian Experience." Review of Policy Research 26(1/2): 77-104.

Druck, G. 2006. "Os sindicatos, os movimentos sociais eo governo Lula: cooptação e resistência." OSAL 6(19): 329-339.

Ebbinghaus, B. and J. Visser. 2000. Trade unions in Western Europe since 1945. London, New York: Macmillan Reference.

ECLAC. 2011. Social Panorama of Latin Qmerica 2011. Santiago: ECLAC Pubblications.

Fairbrother, P. and C. Yates (eds). 2003. Trade Unions in Renewal: A Comparative Study. London: Routledge. 
Ferrarin, A. 2000. "Homo Faber, Homo Sapiens, or Homo Politicus? Protagoras and the Myth of Prometheus." The Review of Metaphysics 54 (2): 289-319.

Fitzgerald, I. and J. Hardy. 2010. "Thinking outside the box? Trade union organizing strategies and Polish migrant workers in the United Kingdom." British Journal of Industrial Relations 48 (1): 137-150.

Frangi, L. 2012. "Variedade de capitalismo e gestão de recursos humanos. O caso das filiais de três multinacionais no Brasil." Economia Global e Gestão, XVII: 83102.

Freeman, R. B. 2009. "Labor Regulations, Unions, and Social Protection in Developing Countries: Market Distortions or Efficient Institutions?" NBER Working Paper Series 14789. National Bureau of Economic Research.

Freeman, R. B. and J. Rogers. 2006. What workers want. Ithaca: Cornell University Press.

French, J. D. 2001. Afogados em Leis. A CLT e a cultura política dos trabalhadores brasileiros. São Paulo: Editora Fundação Perseu Abramo.

Gallin, D. 2001. "Propositions on trade unions and informal employment in time of globalization." Antipode 19(4): 531-549.

Ghosh, B. 2008. "Economic Reforms and Trade Unionism in India-A Macro View." Indian Journal of Industrial Relations 43(3): 355-384.

Gillan, M. and J. Biyanwila. 2009. "Revitalising Trade Unions as Civil Society Actors in India." South Asia: Journal of South Asian Studies 32(3): 425-447.

Guha-Khasnobis, B., R. Kanbur, E. Ostrom (eds). 2006. Linking the Formal and Informal Economy: Concepts and Policies. New York: Oxford University Press.

Haan, A. de and S. Sen. 2007. "Working class struggles, labour elites, and closed shops-The lessons from India's trade unions and experiences of organisation." Pp. 65-82 in Membership-Based Organizations of the Poor, edited by M. Chen, R. Jhabvala, R. Kanbur and C. Richards. New York: Routledge.

Heery, E., S. Williams and B. Abbott. 2012. "Civil society organizations and trade unions: cooperation, conflict, indifference" Work, Employment and Society 26(1): 145-160.

Hill, E. 2010. Worker Identity, Agency and Economic Development: Women's empowerment in the Indian informal economy. New York: Routledge.

Hussmanns, R. 2004. Statistical definition of informal employment: Guidelines endorsed by the Seventeenth International Conference of Labour Statisticians (2003), Geneva: ILO.

Hyman, R. 2002. “The Future of Unions.” Just Labour 1(1): 7-15.

Jackson, J. A. C. 2011. "Off the Books in Salvador. State Regulation, Business Strategies, and Informal Employment." Latin American Perspectives 38(5): 4661. 
Jain, S. C. 2006. Emerging Economies and the transformation of international business. Brazil, Russia, India and china (BRICS). Northampton: Edward Elgar Publishing.

Jütting, J. and J. R. De Laiglesia. 2009. “Is Informal Normal? Towards More and Better Jobs in Developing Countries." OECD Development Centre.

Kapoor, A. 2007. "The SEWA way: Shaping another future for informal labour." Futures 39: 554-568.

Kaufman, B. E. 2004. "Industrial relations in Asia, Africa and Latin America." Pp. 489-548 in The Global Evolution of Industrial Relations: Events, ideas and the IIRA. Edited by B.E. Kaufmann. International Labour Organization, Genève: International Labour Office.

Kaufman, B. E. and T. Daphne G. 2000. Nonunion Employee Representation. New York: Sharpe.

KKPKP Central Secretariat. 2009. "The SWACHH National Alliance of Wastepickers, India." Pp. 37-39 in Refusing to be Cast Aside: Waste-pickers Organising Around the World. Edited by M. Samson. Cambridge, MA: WEIGO.

Kumar, P. and C. Schenk (eds.). 2006. Paths to Union Renewal: Canadian Experiences. Peterborough, ON: Broadview Press Ltd.

Kuruvilla, S. and C. L. Erickson. 2002. "Change and Transformation in Asian Industrial Relations." Industrial Relations 41(2): 171-228.

Levésque, C. and G. Murray. 2006. "How Do Unions Renew? Paths to Union Renewal." Labour Studies Journal 31(3): 1-13.

Lima, J. C. 2007. “Trabalho em cooperativas: dilemas e perspectivas."Pp. 69-80 in A perda da razão social do trabalho: terceirização e precarização, edited by G. Druck and T. Franco (Orgs.). São Paulo: Boitempo.

McNulty, P. J. 1980. The Origins and Development of Labor Economics: A Chapter in the History of Social Thought. Cambridge: MIT Press.

Medina, M. 2007. “Waste-picker Cooperatives in Developing Countries.” Pp. 105121 in Membership Based Organizations of the Poor, edited by M. Chen, R. Jhabvala, R. Kanbur, and C. Richards. London: Routledge.

Mehrotra S. and M. Biggeri (eds). 2007. Asian Informal Workers: Global Risks Local Protection. London: Routledge.

Murillo, M. V. and A. Schrank. 2010. "Labor Organizations and their Role in the Era of Political and Economic Reforms." Pp. 247-268 in How Democracy Works. Political Institutions, Actors, and Arenas in Latin American Policymaking, edited by C. Scartascini, E. Stein and M. Tommasi. Inter-American Development Bank \& David Rockefeller Center for Latin American Studies at Harvard University.

NCEUS. 2007. Report on Conditions of Work and Promotion of Livelihoods in the Unorganised Sector. New Delhi: NCEUS. 
NCEUS. 2008. Report on Definitional and Statistical Issues Relating to Informal Economy. New Delhi: NCEUS.

Noronha, E. G. 2000. "O modelo legislado de relações de trabalho no Brasil." Dados, 43(2). Retrieved April 142014 (http://www.scielo.br/scielo.php?pid=S0011-52582000000200002\&script=sci_arttext).

Pedersini, R. 2010. "Trade union strategies to recruit new groups of workers." Eurofound Paper. Retrieved 05 August 2013 (http:// www.eurofound.europa.eu/docs/eiro/tn0901028s/tn0901028s.pdf).

Pereira, M. G. C. and M. A. C. Teixeira. 2011. “A inclusão de catadores em programas de coleta seletiva: da agenda local à nacional."Cadernos EBAPE 9(3): 895-913.

Pochmann, M. 2007. O emprego na globalização e a nova divisão internacional do trabalho e os caminhos que o Brasil escolheu. São Paulo: Boitempo Editorial.

Ramalho, J. R. 2010. "Flexibilidade e crise do emprego industrial: sindicatos, regiões e novas ações empresariais." Sociologias (UFRGS. Impresso)12: 252284.

Rao, E. M. 2007. "The Rise and Fall of Indian Trade Unions: A Legislative and Judicial Perspective." Indian Journal of Industrial Relations 42(4): 678-695.

Reserve Bank of India. 2008. Internal Working Group to Review the Recommendations of the NCEUS Report on Conditions of Work and Promotion of Livelihoods in the Unorganised Sector. Mumbai: Reserve Bank of India.

Sassen, S. 1994. "The informal Economy: Between New Developments and Old Regulations." The Yale Law Journal 103(8): 2289-2304.

Schneider, B. R. 2009. "Hierarchical Market economies and Varieties of Capitalism in Latin America." Journal of Latin American Studies 41(3): 553-575.

Scott, J. C. 1985. Weapons of the Weak: Everyday Forms of Peasant Resistance. Yale: Yale University Press.

Sen Gupta, A. K. and P. K. Sett. 2000. “Industrial relations law, employment security and collective bargaining in India: myths, realities and hopes" Industrial Relations Journal 31(2): 144-153.

Shekar, N. 2009. "Suman More-KKPKP, Pune, India." Pp. 11-13 in Refusing to be Cast Aside: Waste-pickers Organising Around the World, edited by M. Samson. Cambridge, MA: WEIGO.

Sindzingre, A. 2004. "Truth', 'Efficiency' and 'Multilateral Institutions: A political Economy of Development Economics." New Political Economy 9(2): 233-249.

Sluyter-Beltrão, J. 2010. Rise and Decline of Brazil's New Unionism: The Politics of the Central Unica Dos Trabalhadores. Bern: Peter Lang.

Solidarity Center (2012); “Trade Union Organizing in the Informal Economy: A Review of the Literature on Organizing in Africa, Asia, Latin America, North America and Western, Central and Eastern Europe." Retrieved 15 August 2013 (http:// www.solidaritycenter.org/Files/infecon_rutgers_final.pdf). 
67 Just Labour: A Canadian Journal of Work and Society - Volume 21 - Spring 2014

Souza, D. N. de 2008. " Reestruturação capitalista e trabalho: notas críticas acerca da economia solidária." Revista Katálysis 11(1): 53-60.

Sundar, K. R. S. 2008. "Trade unions in India: from politics of fragmentation to politics of expansion and integration." Pp. 157-176 in Trade Unions in AsiaAn Economic and Sociological Analysis, edited by J. Benson and Y. Zhu. London: Routledge.

Turner, L., H. C. Katz and R. W. Hurd (eds.). 2001. Rekindling the Movement. Labour's Quest for Relevance in the 21 ${ }^{\text {st }}$ Century. New York: Cornell University Press.

Velloso, M. P. 2005. "Os catadores de lixo e o processo de emancipação social." Ciência E Saude Coletiva 10(sup): 49-61.

Wallerstein, I. 2004. World-Systems Analysis - An Introduction. Durham, NC: Duke University Press.

Webster, E. 2011. “Organizing in the Informal Economy: Ela Bhat and the SelfEmployed Women's Association of India." Labour, Capital and Society 44 (1): 98-125.

Weyland K. 2007. “The political economy of market reform and a revival of market structuralism." Latin American Research Review 42(3): 235-250.

Wolcott, S. 2008. "Strikes in Colonial India, 1921-1938." Industrial and Labour Relations Review 61(4): 460-484. 